${ }^{\bullet}$ Entomologica Fennica. 3 July 2002

\title{
The Dorcatoma Herbst, 1792 (Coleoptera: Anobiidae) species of Estonia
}

\author{
Ilmar Süda \& Vitali Nagirnyi
}

\begin{abstract}
Süda, I. \& Nagirnyi, V. 2002: The Dorcatoma Herbst, 1792 (Coleoptera: Anobiidae) species of Estonia. — Entomol. Fennica 13: 116-122.

The collection specimens of the genus Dorcatoma Herbst, 1792 were revised for Estonia. A substantial part of the material was reared from fruiting bodies of bracket fungi. Seven species of the genus are found in the country. Five of them, D. flavicornis F., D. substriata Hummel, D. punctulata Mulsnat \& Rey, D. robusta Strand and D. lomnickii Rtt. are new for Estonia, the last also being new for the Northern Europe and Eastern Baltic regions. Data on the ecology and distribution of the species in Estonia are presented. Comments are given on the systematics and geographical distribution of $D$. lomnickii and D. obtrita Logv.

Ilmar Süda, Forest Research Institute, Estonian Agricultural University, Kreutzwaldi 5, 51014 Tartu, Estonia; E-mail: isyda@eau.ee

Vitali Nagirnyi, Narva mnt. 131-1, 51008 Tartu, Estonia; E-mail: vetal@fi.tartu.ee
\end{abstract}

Received 15 October 2001, accepted 24 January 2002

\section{Introduction}

The genus Dorcatoma Herbst, 1792 comprises over 70 species worldwide (Borowski 1999). The genus is poorly investigated even in Europe, mainly because of the morphological similarities and secretive habits of adult beetles. Therefore, it is not surprising that new Dorcatoma species have recently been described from Europe (Baranowski 1985, Zahradnik 1993a), and that entomologists are still arguing about the synonymity of several species (e.g. Borowski 1999). Presently, only two species, D. chrysomelina Sturm, 1837 and D. dresdensis Herbst, 1792 have been reported from Estonia (Szeliga-Mierzeyewski 1942, Miländer 1993, 1999), while eight species in all are known from Northern Europe and the Baltic countries (Silfverberg 1992, Jonsell 1998). Considering the general distribution of Dorcatoma species, one would suspect that widespread European species, such as D. robusta or D. punctulata, might simply have been overlooked in Estonia. With this concern in mind, we planned to study the material of this genus available in Estonia. Since the material in collections was relatively scanty, we also reared out beetles from fruiting bodies of bracket fungi collected in the field. This study resulted in the discovery of five species new for Estonia, making the total number of Dorcatoma species seven. Distribution maps are given for all species found in Estonia.

\section{Material and methods}

We examined material from the collections of the Institute of Zoology and Botany (Tartu), including the collection of J. Mieländer; the Estonian Museum of Natural History (Tallinn), including the collection of V. Soo; the Zoologi- 
cal Museum of Tartu University (Tartu); the Institute of Plant Protection (Tartu) and the Forest Research Institute (Tartu), as well as the private collections of the authors and those of G. Miländer, U. Roosileht and H. Õunap.

The bulk of material studied was reared from dead fruiting bodies of Fomes fomentarius, Phellinus igniarius, Phellinus nigricans, Phellinus cinereus, Phellinus tremulae, Phellinus populicola, Fomitopsis pinicola, Inonotus radiatus, Inonotus rheades and Ganoderma applanatum. The fruiting bodies were collected in early spring or late autumn. They were placed into a light-tight box supplied with a small transparent window in the upper part that can be used for hatched beetles attracted to light (photoeclector). A hole was made in the window and through this hole a transparent jar for collecting beetles was attached to the box with the aid of a short plastic tube. Emerged beetles crawled up towards the light and into the jar. The rearing boxes were kept at room temperature or in an unheated room, where temperatures were several degrees higher than outdoor temperatures. We did not, therefore, record the date of hatching. The dates given in the material list for each species refer to the dates of collecting of fungi. A few specimens were collected in the nature from bracket fungi, or were caught occasionally while sweeping the forest vegetation with a net. A few specimens were reared from red wood rot taken from trees infested with Laetiporus sulphureus.

The distribution maps were prepared using the UTM $10 \times 10-\mathrm{km}$ grid system.

\section{Results and discussion}

An annotated list of Dorcatoma species found in Estonia is presented below. Species reported for the first time from the territory are denoted by an asterisk $(*)$.

\section{*Dorcatoma flavicornis (Fabricius, 1792)}

Material. Saaremaa Island, Kuressaare, Loode oak grove, 19.VII.1998, 2 O’, 1 \&, V. Nagirnyi.

Distribution and ecology. D. flavicornis is rare in Estonia, found in only one locality (Fig. 1a). The specimens were beaten from dead oak branches lying on the ground under oak trees.

\section{Dorcatoma chrysomelina Sturm, 1837}

Literature. Szeliga-Mierzeyewski (1942).

Material. .̈sel, Parrasmetz (= Saaremaa Island, Parasmetsa), 26.VII.1933, 1, Mierzeyewski
(Szeliga-Mierzeyewski 1942); Rakvere, Vinni, from dry oak rot, 4.VII.1965, 8, V. Soo; Laanemetsa $4 \mathrm{~km} \mathrm{SW}$, Laetiporus sulphureus on willow, 30.VII.1996, 1, I. Süda; Saaremaa Island, Kuressaare, Loode oak grove, Laetiporus sulphureus on oak, 20.VII.1997, 1, I. Süda; Saaremaa Island, Kuressaare, Loode oak grove, Laetiporus sulphureus on oak, 19.VII.1998, 1, V. Nagirnyi; Saaremaa Island, Viidumäe Nature Reserve, Audaku $3 \mathrm{~km} \mathrm{~N}$, reared from oak rot, 16.VI.2001, 9, I. Süda; Saaremaa Island, Kuressaare, Loode oak grove, from oak rot, 5.VII.2001, 3, I. Süda.

Distribution and ecology. In spite of the fact that $D$. chrysomelina is the first Dorcatoma species reported from Estonia, it is one of the rarest species in our fauna, found in five localities only (Fig. 1b). It was found on oaks and once on a willow with red rot caused by the fungus Laetiporus sulphureus.

\section{*Dorcatoma substriata Hummel, 1829}

=D. serra (Panzer, 1795 nec Fabricius, 1792) (Silfverberg 1992)

Material. Soontaga, reared from Fomes fomentarius on birch, 26.V.1995, 1 O’, I. Süda; Soontaga $2 \mathrm{~km} \mathrm{NW}$, reared from Inonotus radiatus on alder, 7.V.1999, 4 ơ', 1 \&, I. Süda.

Distribution and ecology. D. substriata is a rare species in Estonia, known from two localities only (Fig. 1c). It was reared from Inonotus radiatus and Fomes fomentarius. To our knowledge, D. substriata has not been reared from Fomes fomentarius before. This is also true for Sweden, where 811 fruiting bodies of $F$. fomentarius have been analysed (Jonsell 1998). Up to now, D. substriata has been found on five fungal species, all belonging to the genus Inonotus (Koch 1989, Jonsell 1998, Nikitsky et al. 1998). On the other hand, it is the species Dorcatoma minor Zahradník, 1993, habitually highly similar to $D$. substriata, which is known to breed in Fomes fomentarius (Jonsell 1998; Borowski 1999). Bearing all this in mind, we checked a preparation of the genitalia of the Estonian specimen reared from $F$. fomentarius. The result, however, confirmed that the specimen under discussion belongs to $D$. substriata. 

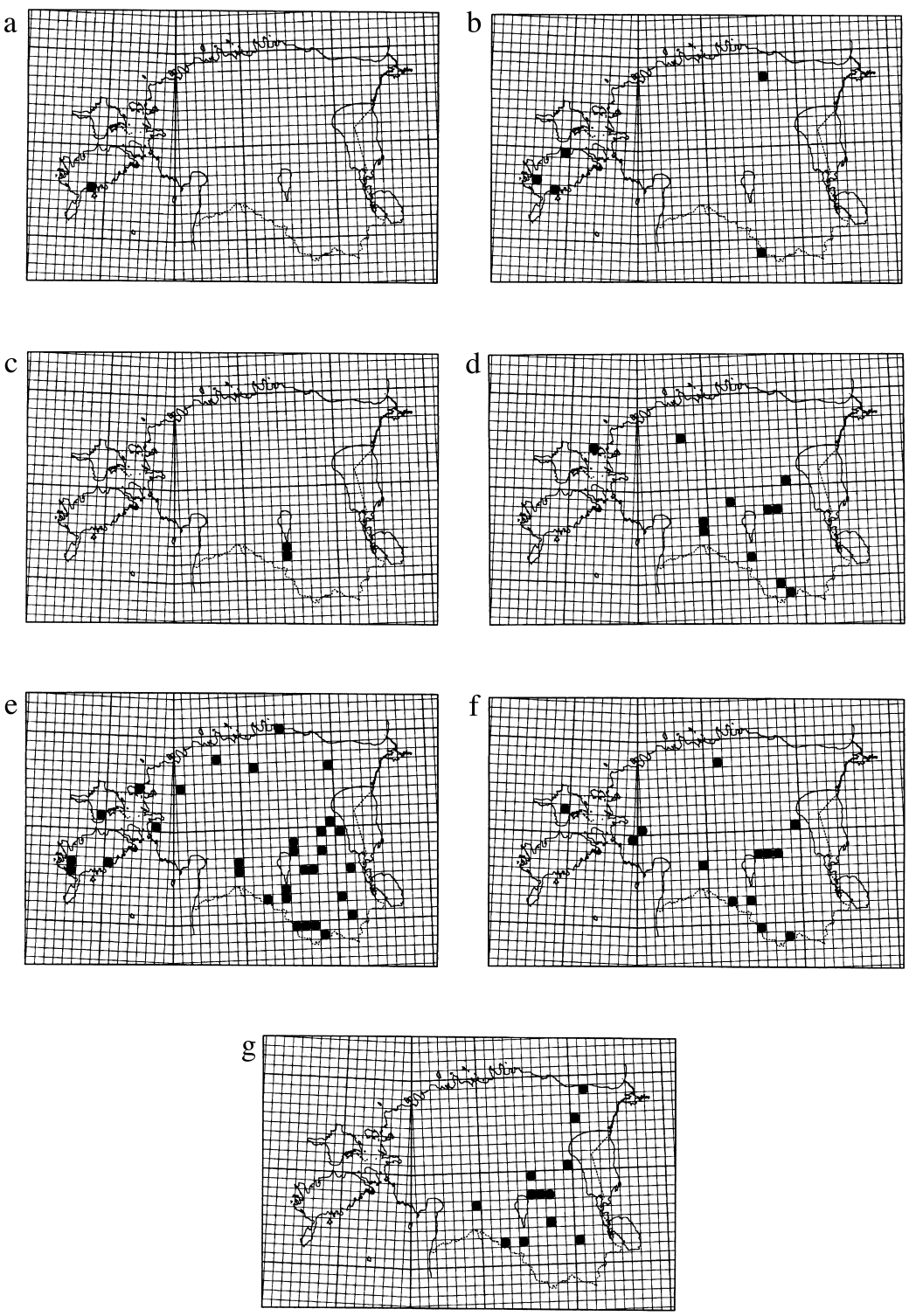

Fig. 1. The distribution maps of Dorcatoma species in Estonia. - a. D. flavicornis. — b. D. chrysomelina. - c. D. substriata. - d. D. punctulata. - e. D. dresdensis. - f. D. robusta. - g. D. lomnickii.

*Dorcatoma punctulata Mulsant \& Rey, 1864

Material. Lohu, mixed forest margin, from grass, 19.VII.1960, 1, V. Soo; Kanaküla, mixed forest, from grass, 17.VI.1964, 1, V. Soo; Krabi, Seveli, clearing, rotten birch, 21.VI.1967, 1, V. Soo; Viljandi, Aimla, clearing, from grass, 29.VI.1971, 1, V. Soo; Vormsi Island, Suuremõisa $1 \mathrm{~km} \mathrm{~S}$, birch stump, polypore fungus, 8.VI.1993, 1, G. Miländer (Miländer 1999, as D. dresdensis); Kanaküla, 9.VII.1993, 1, U. Roosileht; Soontaga, reared from Fomitopsis pinicola on birch, 26.V.1995, 3, I. Süda;
Tartu, Tiksoja, reared from $F$. pinicola, 17.IV.1999, 2, V. Nagirnyi; Soontaga, reared from $F$. pinicola on spruce stub, 7.V.1999, 13, I. Süda; Valmaotsa 4 $\mathrm{km} \mathrm{S}$, reared from $F$. pinicola on a pine stump, 25.V.1999, 3, I. Süda; Kaugjärv lake shore, reared from $F$. pinicola on birch, 12.VI.1999, 3, I. Süda; Jõemõisa lake shore, reared from $F$. pinicola on lime, 22.IV.2001, 8, I. Süda.

Distribution and ecology. D. punctulata is a relatively common species in Estonia, spread all over the territory (Fig. 1d). Reared only from Fomitopsis pinicola on spruce, pine, birch and lime. 


\section{Dorcatoma dresdensis Herbst, 1792}

Literature. Miländer (1993), Miländer (1999).

Material. Võsu, Esku, VII.1931, 1, Vannary; Aegviidu, Mustjõe, fungus on rotten birch, 27.VI.1947, 1, V. Soo; Tohkri, 6.VI.1949, 1, J. Mieländer; Risti, Metsa, woodland, from grass, 6.VII.1952, 1, V. Soo; Krabi, Seveli, 3.VI.1960, 5, J. Mieländer; Risti, Metsa, woodland, dry aspen, 30.VII.1961, 1, V. Soo; Hiiumaa Island, Jausa, 22.VI.1972, 1, J. Mieländer; Kanaküla, Riimaru, clearing margin, from grass, 11.VII.1977, 1, V. Soo; Järvselja, under spruce bark, dead, 7.V.1984, 1, I. Süda; Risti, Metsa, 15.VI.1984, 2, U. Roosileht; Järvselja, 8.VI.1985, 1, U. Roosileht; Kanaküla, from grass, 21.VII.1992, 1, U. Roosileht; Tartu, Kõrveküla, Phellinus igniarius on willow, 2.VI.1993, 8, V. Nagirnyi; Tallinn, Tammetalu, 5.VI.1993, 2, U. Roosileht; Vormsi Island, Hullo $1.5 \mathrm{~km}$ E, fungus on birch, 5.VI.1993, 1, G. Miländer; Kanaküla, 25.VI.1993, 1, U. Roosileht; Tartu, Kõrveküla, Phellinus igniarius on willow, 28.VI.1993, 1, V. Nagirnyi; Kõmsi, Salevere, reared from Fomes fomentarius on birch, 8.VI.1994, 9, H. Öunap; Taagepera $6 \mathrm{~km} \mathrm{~S}$, reared from Fomes fomentarius on birch, 26.IV.1995, 2, I. Süda; Viisjaagu lake shore, reared from Phellinus igniarius on willow, 1.V.1995, 1, I. Süda; Soontaga, reared from Fomes fomentarius on birch, 26.V.1995, 2, I. Süda; Himma, Sika, reared from Ganoderma applanatum on lime, 29.V.1995, 154, I. Süda; Puhja, Saare, reared from Fomes fomentarius on birch, 23.VI.1996, 2, V. Nagirnyi; Saaremaa Island, Kõljala, swept from bushes, 15.VI.1998, 1, I. Süda; Elva, Peedu, 24.VI.1998, 1, V. Nagirnyi; Alam-Pedja Nature Reserve, Selli, reared from Inonotus rheades on aspen, 22.IV.1999, 5, I. Süda; Tartu, Maramaa, reared from Phellinus tremulae on aspen, 24.IV.1999, 2, I. Süda; Tartu, Maramaa, reared from Phellinus cinereus on birch, 24.IV.1999, 4, I. Süda; Tartu, Maramaa, reared from Fomes fomentarius on alder, 24.IV.1999, 3, I. Süda; Tartu, Maramaa, reared from Inonotus radiatus on alder, 24.IV.1999, 3, I. Süda; Soontaga $2 \mathrm{~km} \mathrm{NW}$, reared from Inonotus radiatus on alder, 7.V.1999, 9, I. Süda; Alam-Pedja Nature Reserve, Utsali, reared from Phellinus tremulae on aspen, 3.VI.1999, 5, I. Süda; Kaugjärv lake shore, reared from Phellinus nigricans on birch, 12.VI.1999, 4, I. Süda;
Koobassaare $4 \mathrm{~km}$ E, from Phellinus nigricans on birch, 13.VI.1999, 1, I. Süda; Koikküla, Fomes fomentarius on birch stub, 14.VI.1999, 1, I. Süda; Alam-Pedja Nature Reserve, Nõmmeotsa, Inonotus radiatus on alder, 20.VI.1999, 3, I. Süda; Luke, park, Ganoderma applanatum on willow, 24.VI.1999, 2, I. Süda; Riimaru 2 km N, reared from Phellinus tremulae on aspen, 7.V.2000, 7, I. Süda; Kaiu lake shore, reared from Phellinus nigricans on birch, 22.IV.2001, 47, I. Süda; Pataste 4 km N, reared from Phellinus igniarius on willow, 22.IV.2001, 4, V. Nagirnyi; Vaitka, Koiva woodland, Phellinus igniarius on willow, 6.VI.2001, 1, I. Süda; Vaitka, Koiva woodland, reared from Phellinus igniarius on willow, 6.VI.2001, 2, I. Süda; Järvselja virgin forest, reared from Phellinus nigricans on birch, 9.VI.2001, 12, B. Ehnström; Tudu 5 km NE, reared from Phellinus tremulae on aspen, 10.VI.2001, 4, I. Süda; Tudu $5 \mathrm{~km}$ NE, reared from Phellinus nigricans on birch, 10.VI.2001, 3, I. Süda; Saaremaa Island, Viidumäe Nature Reserve, Mäebe, reared from Phellinus nigricans on birch, 14.VI.2001, 1, I. Süda; Saaremaa Island, Viidumäe Nature Reserve, Kivesselja, reared from Inonotus radiatus on alder, 14.VI.2001, 2, I. Süda; Saaremaa Island, Viidumäe Nature Reserve, Mäebe, reared from Inonotus radiatus on hazel, 15.VI.2001, 3, I. Süda; Padakõrve $1 \mathrm{~km} \mathrm{~N}$, reared from Phellinus populicola on aspen, 29.VI.2001, 5, H. Õunap; Nõo $2 \mathrm{~km}$ SE, Phellinus igniarius on willow, 12.VII.2001, 2, I. Süda.

Distribution and ecology. D. dresdensis is the most common species in Estonia, spread all over the territory (Fig. 1e). It is a polyphagous species reared in Estonia from Fomes fomentarius on birch and alder, from Phellinus igniarius on willow, from Phellinus tremulae and Phellinus populicola on aspen, from Phellinus cinereus on birch, from Inonotus radiatus on alder and hazel, from Inonotus rheades on aspen and from Ganoderma applanatum on lime.

\section{*Dorcatoma robusta Strand, 1938}

Material. Aegviidu, Mustjõe, fungus on rotten birch, 27.VI.1947, 1, V. Soo; Aegviidu, Mustjõe, fungous birch, 9.VI.1948, 1, V. Soo; Krabi, Seveli, 1.VI.1960, 1, J. Mieländer; Krabi, Seveli, 3.VI.1960, 1, J. Mieländer; Krabi, Seveli, 4.VI.1960, 1, J. 
Mieländer; Krabi, Seveli, 8.VI.1960, 2, J. Mieländer; Hiiumaa Island, Männamaa, 13.VI.1969, 2, J. Mieländer (Miländer 1993, as D. dresdensis); Oidrema, 8.VII.1974, 2, J. Mieländer; Karinõmme, Tarva, Fomes fomentarius on birch stub, 16.VII.1985, 1, I. Süda; Kanaküla, 9.VII.1993, 1, U. Roosileht; Taagepera $6 \mathrm{~km} \mathrm{~S}$, reared from Fomes fomentarius on birch, 26.IV.1995, 13, I. Süda; Soontaga, reared from Fomes fomentarius on birch, 26.V.1995, 2, I. Süda; Vorbuse $1.5 \mathrm{~km}$ SW, reared from Fomes fomentarius on birch, 11.V.1996, 8, I. Süda; Koikküla, Fomes fomentarius on birch stub, 2.VII.1997, 2, I. Süda; Laeva, Kärevere, reared from Fomes fomentarius, 1.XI.1998, 100, V. Nagirnyi; Palupõhja, reared from Fomes fomentarius on birch, 15.V.1999, 4, V. Nagirnyi; Kaiu lake shore, reared from Fomes fomentarius on birch, 22.IV.2001, 11, V. Nagirnyi; Koikküla, reared from Fomes fomentarius on birch, 2.VI.2001, 2, I. Süda.

Distribution and ecology. D. robusta was described as late as in 1938 and remained unknown to Estonian collectors for a relatively long time. It is often confused with $D$. dresdensis, as the two species are morphologically similar. All the material of this species, preserved in older collections, was identified as $D$.dresdensis. D. robusta is quite a common species in Estonia, spread all over the territory (Fig. 1f). All the reared specimens originated invariably from Fomes fomentarius on birch. This confirms that D. robusta is a monophagous species (Palm 1959, Jonsell 1999).

\section{*Dorcatoma lomnickii Reitter, 1903}

Material. Kanaküla, 25.VI.1993, 1, U. Roosileht; Taagepera $6 \mathrm{~km} \mathrm{~S}$, reared from Fomes fomentarius on birch, 26.IV.1995, 4, I. Süda; Soontaga, reared from Fomes fomentarius on birch, 26.V.1995, 6, I. Süda; Himma, Sika, reared from Ganoderma applanatum on lime, 29.V.1995, 8, I. Süda; Vorbuse $1.5 \mathrm{~km} \mathrm{SW}$, reared from Fomes fomentarius on birch, 11.V.1996, 8, I. Süda; Laeva, Kärevere, reared from Fomes fomentarius, 1.XI.1998, 4, V. Nagirnyi; Ontika, reared from Fomes fomentarius on birch, 17.IV.1999, 13, I. Süda; Soontaga, reared from Fomes fomentarius on alder, 7.V.1999, 11, I. Süda; Puurmani, Jüriküla, reared from Fomes fomentarius on al- der, 14.V.1999, 25, I. Süda; Puhja, Saare, reared from Fomes fomentarius on birch, 10.III.2001, 5, V. Nagirnyi; Kaiu lake shore, reared from Fomes fomentarius on birch, 22.IV.2001, 1, I. Süda; Pangodi $2 \mathrm{~km}$ SE, reared from Fomes fomentarius on birch, 19.V.2001, 8, I. Süda; Tudu, Oonurme $4.5 \mathrm{~km}$ E, reared from Fomes fomentarius on birch, 10.VI.2001, 4, I. Süda.

Distribution and ecology. In Estonia, D. lomnickii is a relatively common species found in the eastern part of the territory (Fig. 1g). Analysis of known localities revealed that unlike the other species, D. lomnickii prefers moist forests. It is reared mainly from Fomes fomentarius on birch and alder, sometimes together with $D$. dresdensis or D. robusta. On one single occasion it was also reared from Ganoderma applanatum on lime.

Remarks on systematics. D. lomnickii has been described by Reitter (1903) on the basis of three specimens collected in the vicinity of Minsk (present Byelorussia). Only a few specimens of this species have been found since its description. It has been included in the checklist of Slovakian Anobiidae (Zahradnik 1993b). Only three female specimens have been reported from the European part of the former Soviet Union (Logvinovskij 1980, 1985). Males were stated to be unknown. D. lomnickii has been included in several keys to European beetles, based mainly on Reitter's original description but without indication of new finds (Dominik 1955, Lohse 1968). Baranowski (1985) studied Reitter's type series of D. lomnickii in the Hungarian Natural History Museum, Budapest and published the first drawings of male genitalia after two syntype specimens had been identified as male (Fig. 2a). He also presented a very sophisticated and detailed identification key to Central and North-European species, including $D$. lomnickii. No additional specimens were indicated besides a type series. Recently, D. lomnickii has been reported as a new species for Poland on the basis of finds in several localities (Borowski 1999). Borowski produced a subgeneric division as well as compiled an interesting identification key based on new characteristics for Central European Dorcatoma species. In the same paper, a drawing of the male genitalia (Fig. 2b) differs slightly from the one drawn by Baranowski (1985). For comparison, we have produced a photographic image of typical male genitalia taken 
Fig. 2. Male genitalia of $D$. lomnickii $(\mathrm{a}-\mathrm{c})$ and $D$. obtrita (d). - a. Type series after Baranowski (1985). — b. Poland, after Borowski (1999). - c. Estonia. - d. After Logvinovskij (1980).

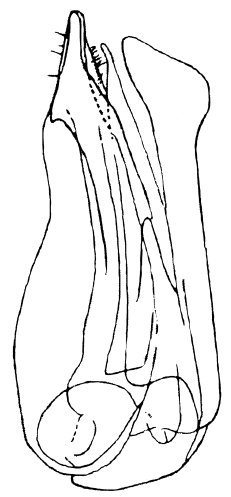

a

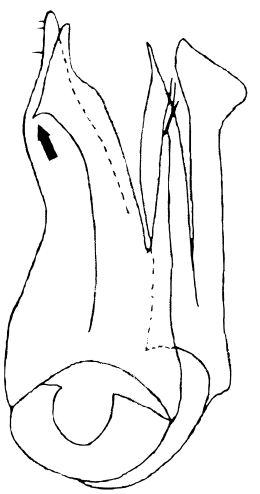

b

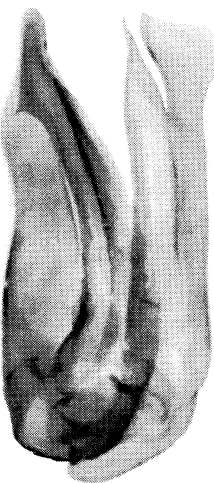

c

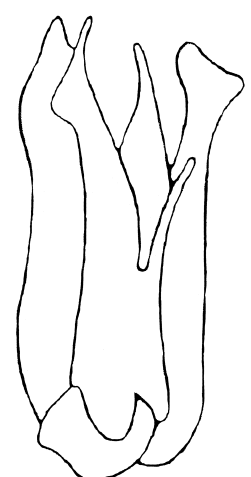

d from Estonian specimens (Fig. 2c). Both undoubtedly confirm that the beetles collected in Estonia belong to the species $D$. lomnickii.

The distribution of $D$. lomnickii is not yet clear. Borowski (1999) treated D. obtrita Logvinovskij, 1980, a species described from the Russian Far East (Logvinovskij 1980), as a synonym of $D$. lomnickii without indicating any plausible reasons for synonymizing. In the same study, D. lomnickii is named a Siberian species with its distribution extending as far west as Poland. This seems doubtful for several reasons. The known material of $D$. obtrita is confined to the area of the Russian Far East. There are no indications of the occurrence of this species over the huge territory from the Khabarovsk region in the Far East to the Central European part of Russia. On the other hand, reliable easternmost finds of $D$. lomnickii have been reported from the Bryansk and Kirov districts in European Russia (Logvinovskij 1985).

The original description indicates several explicit characteristics for distinguishing D. obtrita from $D$. lomnickii; however, it appears to be too brief and schematic. These characteristics are a gold-coloured and shiny pubescence and a relatively sparse punctuation of the elytra. Moreover, the male genitalia of $D$. lomnickii display a distinctive feature (arrow in Fig. 2b) which is very stable and can hardly be overlooked. On the drawing of the genitalia of D. obtrita (Fig. 2d, reproduced from Logvinovskij 1980, 1985), this feature is lacking altogether. In our opinion, making a judgement on the synonymity of $D$. obtrita and D. lomnickii requires further research. The type material of $D$. obtrita, as well as the distribution of both species, are yet to be examined.

The finds in Estonia are the northernmost ones for $D$. lomnickii. The species is new not only for Estonia but also for the Baltic countries and Northern Europe. Taking into account the finds of $D$. lomnickii in Byelorussia, Poland and Estonia, the occurrence of this species in Lithuania and Latvia seems to be highly probable.

Acknowledgements. The present investigation was supported by the Estonian Science Foundation (grant no. 2684). We are much indebted to Prof. E. Parmasto for the identification of some polypores and to G. Miländer, U. Roosileht and $\mathrm{H}$. Ounap for allowing the use of material from their private collections for study. We are grateful to Roger de Keyzer and George Hangay for valuable comments on the paper and to Ester Jäigma for language correction.

\section{References}

Baranowski, R. 1985: Central and Northern European Dorcatoma (Coleoptera: Anobiidae), with a key and description of a new species. - Ent. Scand. 16: 203-206.

Borowski, J. 1999: A contribution to the Central European species of the genus Dorcatoma Herbst, 1792 (Coleoptera, Anobiidae, Dorcatominae). - Annals of Warsaw Agricultural University, SGGW, Forestry and Wood Technology 49: 127-136.

Dominik, J. 1955: Klucze do oznaczania owadów Polski. 19, Chrząszcze - Coleoptera, 41, Kołatki - Anobiidae. - PWN, Warszawa. 69 pp.

Jonsell, M. 1998: En ny tickgnagare i Sverige, Dorcatoma minor Zahradnik (Coleoptera: Anobiidae), och dess värdval. — Ent. Tidskr. 119 (2): 105-109.

Jonsell, M. 1999: Insects on wood decaying polypores - 
conservation aspects. - Ph. D. thesis, SLU, Uppsala. Koch, K. 1989: Die Käfer Mitteleuropas. Ökologie. 2. — Goecke \& Evers, Krefeld. 382 pp.

Logvinovskij, V. D. (Логвиновский, В. Д.) 1980: A review of the genus Dorcatoma Herbst (Coleoptera, Anobiidae) in fauna of the USSR. - Revue d'Entomologie de l'URSS 59 (1): 148-153. [In Russian].

Logvinovskij, V. D. (Логвиновский, В. Д.) 1985: [Fauna of USSR. Coleopterous insects. 14 (2). Deathwatch Beetles — family Anobiidae.] — Nauka, Leningrad. 175 pp. [In Russian].

Lohse, G.A. 1968: Familie Anobiidae. — In: Freude, H., Harde, K. W., Lohse, G. A. (eds.), Die Käfer Mitteleuropas 8: 26-59. Goecke and Evers, Krefeld. 388 pp.

Miländer, G. 1993: Hiiumaa mardikalised (Coleoptera). Pirrujaak 2. Biosfääri Kaitseala Hiiumaa Keskus, Kärdla. 120 pp.

Miländer, G. 1999: Huvitavamaid leide Eesti mardikalistest (Coleoptera). - Lepidopteroloogiline Informatsioon 11: 52-58.

Nikitsky, N. B., Semenov, V. B. \& Dolgin, M. M. (Никитский, Н. Б., Семенов, В. Б. \& Долгин, М.
M.) 1998: The beetles of the Prioksko-Terrasny Biosphere Reserve - xylobiontes, mycetobiontes and Scarabaeidae (with the review of the Moscow region fauna of these groups). - Arch. Zool. Mus. Moscow Univ. 36, Suppl. 1.61 pp. [In Russian].

Palm, T. 1959: Die Holz- und Rinden Käfer der Süd- und Mittelschwedishe Laubbäume. - Opusc. Entomol. Suppl. 16.

Reitter, E. 1903: Dorcatoma Lomnickii n. sp. - Wiener Entomologische Zeitung 22 (9): 239.

Silfverberg, H. 1992: Enumeratio Coleopterorum Fennoscandiae, Daniae et Baltiae. - Helsingin Hyönteisvaihtoyhdistys, Helsinki. 94 pp.

Szeliga-Mierzeyewski, W. v. 1942: Verzeichnis der Käfer Ösels in meiner Insektensammlung. — Korrespondenzbl. Naturt. (Riga) 64: 180-230.

Zahradnik, P. 1993a: New species of the genus Dorcatoma from Central Europe (Coleoptera, Anobiidae). - Folia Heyrovskyana 1(8): 80-83.

Zahradnik, P. 1993b: Anobiidae. — In: Jelinek, Y. (ed.), Check-list of Czechoslovak Insects 4 (Coleoptera): 8688. Folia Heyrovskyana, Suppl. 1, Prague. 